has frequently involved a full day's discussion, which has been of the greatest advantage from a practical standpoint, but possibly even more so from a psychological standpoint.

So far as the work of the Utilization Committee of the Canadian Society of Forest Engineers is concerned, it would, therefore, seem advisable not to duplicate work already served adequately by other organizations, but rather to pay attention to utilization problems more closely related to forestry, as it is generally understood, or in other words, to border-line problems. The most important problem in my opinion in forestry is to properly relate or co-ordinate forestry and utilization, and to broaden in the minds of foresters and others the conception of forestry.

While the rounding out of a programme will have to await the attention of the Committee when formed, a few problems suggest themselves, as for example:

(a) The utilization of logging and mill waste by chemical or mechanical conversion, waste for fuel, etc.

(b) The use of species such as white birch, poplar, and certain other hardwoods.

(c) The use of built up members in large structures due to the increasing difficulty of obtaining large timbers in some districts.

(d) The use of wooden connectors in the design of wonden structures.

(e) Charcoal or wood as a fuel for internal combustion engines in logging operations.

(f) Improvements in logging and milling equipment. Greater mechanization to reduce costs and permit competition with substitutes.

(g) The species and quality of timber which should be produced in the forest, to meet requirements of the lumber industry.

To adequately deal with some of these problems, there must be a combination of effort of foresters and utilization officers. So far as the Committees of this Society are concerned, the Utilization and Operation Committees will have to work together in many instances in devising methods of attack on some of these problems.

\title{
REPORT OF THE SUB-COMMITTEE ON WOODS OPERATIONS C.S.F.E.
}

\section{Personnel}

$$
\text { JANUARY-1936 }
$$

The Committee at present is made up by Messrs. A. M. Koroleff (Chairman), Howard Kennedy, L. Schuelt, B. V. Avery, and J. D. B. Harrison 


\section{REPORT ON WOODS OPERATIONS}

(Secretary). It is intended to invite additional persons to become members, so that all parts of the country may be represented.

\section{Meetings}

The Chairman and Secretary held a preliminary discussion in Montreal in August, 1935. A meeting of the sub-committee was held in the Chateau Laurier, 11 January, 1936.

\section{Progress}

The principal field of work of this sub-committee is closely allied to a co-operative project in the study of commercial silviculture, now under consideration by the Dominion Forest Service and the Woodlands Section. Both Chairman and Secretary of this sub-committee have been engaged in connection with the latter project, and it has not proved practicable to further the work of the sub-committee beyond the stage of preparing a list of problems which we recommend for consideration by the Committee on Research.

\section{Recommendations}

In our opinion, the principal projects requiring study in connection with woods operations are as follows:

1. Silviculture

(a) Preparation of Manual for Wood lot Owners.

(b) Preparation of Manual for instruction of lumber jacks and woods executives.

(c) Preparation of data to form basis for lectures to woods personnel.

(d) Studies of cutting methods.

(e) Studies of soils in relation to silviculture and utilization.

2. Waste in Woods Operations

(a) Waste of effort in logging through the use of poor equipment and tools, or through poor organization.

(b) Waste of material in logging.

3. Roads

(a) Methods of construction.

(b) Possible co-operation in road construction between industry, municipalities and provincial governments.

(c) Possibilities of establishing permanent transportation systems.

4. Mechanical Transport

(a) Trucks (Diesel, gasoline and producer gas).

(b) Tractors (Diesel and gasoline).

5. Cordwood

(a) Development of markets for wood fuel, as an aid to silviculture and management. 
6. Unemployment Relief Work

(a) Possible improvements in methods of use in connection with Forest Management.

7. Experimental Stations

"(a) Survey of system of experiment stations with relation to their functions.

8. Establishment of a Logging Experiment Station:

Chairman 